\title{
15. Türkiye Türkçesindeki renklerle ilgili kavram işaretlerinin kavram işaretleme yöntemlerine göre incelenmesi
}

\section{Osman MERT ${ }^{1}$}

\section{Bahattin ŞİMŞEK²}

APA: Mert, O.; Şimşek, B. (2021). Türkiye Türkçesindeki renklerle ilgili kavram işaretlerinin kavram işaretleme yöntemlerine göre incelenmesi. RumeliDE Dil ve Edebiyat Araşturmaları Dergisi, (23), 227-247. DOI: 10.29000/rumelide.948333.

\section{$\ddot{\mathbf{O} z}$}

İnsanlar, üzerinde yaşadıkları coğrafyada gördükleri, geliştirdikleri, ulaşabildikleri ne kadar soyut ya da somut kavram var ise bunların tamamını sözcükler/sözcük grupları... ile işaretler ve böylelikle diller ve dillerin söz varlığı ortaya çıkar. Bir dilin sözvarlığı içinde renk ve renk algısı sadece fizikî, biyolojik ve kimyasal olarak algllanmamaktadır. Kültürler, renklere farklı anlamlar da yüklemekte ve bu anlamlardan hareketle renklerle ilgili yeni kavramlar da ortaya çıkabilmektedir. Bu kavramları oluşturmak için diller, tarihî süreçte kültürün geliştirdiği, karşlaştığı kavramları ya fonetik, morfolojik ve sentaktik kuralları çerçevesinde kendine ait kavram işaretleme metotları ile işaretlemekte ya da işaretleyeceği kavramın kodunu ödünçleme yoluna gitmektedir. Bu bağlamda çalışma, Türkçede renk adlarının ve renklerle ilgili eylemlerin hangi kavram işaretleme yöntemlerine göre oluşturulduğunu tespit ve tasnif etmeyi amaçlamaktadır. Çalışmada nitel araştırma yöntemlerinden doküman incelemesi yöntemi kullanılmıştır. Çalışmanın verilerini, Kaymaz’ın (1997) Türkiye Türkçesi ve Ağızlarında Renk Bildiren Kelimelerin Kullanılışı ve Sistematiği ile S. Küçük’ün (2010) Türkiye Türkçesinde Renk Adları ve Özellikleri adlı çalışmalarında yer alan renk adları oluşturmaktadır. Renk adları dört ana başlık altında tasnif edilmiştir. Veri analizi sonucu toplam 1269 renk adının 549'unu (\%43,2) "kök, köken ve gövde hâlindeki renk adları” 614'ünü $(\% 48,4)$ "birden fazla anlam ögesiyle kurulmuş renk adları”, 71'ini $(\% 5,6)$ "renklerle ilgili fiil kök, köken ya da gövdeleri” ve 35’ini $(\% 2,8)$ "renk adlariyla kurulan deyimler" ile oluştuğu tespit edilmiştir. Türkçenin üretme ve türetme gücünün diğer alanlarda olduğu gibi renk adlarında da etkili bir şekilde kullanıldığı; döneme, coğrafyanın özelliklerine ve içinde yaşanılan kültüre göre renk adlarının çeşitlilik gösterdiği dikkati çekmektedir.

Anahtar kelimeler: Renk adları, kavram işareti, kavram işaretleme yöntemleri

\section{The analysis of the term significations related to color names in Turkish according to the term signification methods}

\begin{abstract}
People mark all of the abstract or concrete concepts that they see, develop and reach in the geography they live on with words / phrases and thus the languages and vocabulary of languages emerge. Within the vocabulary of a language, color and color perception are not perceived only physically, biologically and chemically. Cultures also attribute different meanings to colors and new
\end{abstract}

Prof. Dr., Atatürk Üniversitesi, Kâzım Karabekir Eğitim Fakültesi, Türkçe ve Sosyal Bilgiler Eğitimi Bölümü, Türkçe Eğitimi ABD (Erzurum, Türkiye), osmnmert@gmail.com, ORCID ID: oooo-0oo1-6159-1906 [Araștırma makalesi, Makale kaylt tarihi: 20.03.2021-kabul tarihi: 20.06.2021; DOI: 10.29000/rumelide.948333]

Öğr. Gör. Dr., Atatürk Üniversitesi, Türkçe Öğretimi Araştırma ve Uygulama Merkezi (TÖMER) (Erzurum, Türkiye), b.simsek@atauni.edu.tr, ORCID ID: 00oo-0001-9707-5313

Adres | Address

RumeliDE Dil ve Edebiyat Araşttrmalar Dergisi $\quad$ RumeliDE Journal of Language and Literature Studies Osmanağa Mahallesi, Mürver Çiçeği Sokak, No:14/8 Osmanağa Mahallesi, Mürver Çiçeği Sokak, No:14/8

Kadıköy - İSTANBUL / TÜRKIYE 34714 Kadıköy - ISTANBUL / TURKEY 34714 e-posta: editor@rumelide.com

e-mail: editor@rumelide.com

tel: +90 505 7958124, +90 2167730616 phone: +90 505 7958124, +90 2167730616 
The analysis of the term significations related to color names in Turkey's Turkish according to the term signification methods / O. Mert; B. Şimşek (pp. 227-273)

terms related to colors may emerge from these meanings. In order to create these terms, languages either mark the terms which the culture developed and encountered in the historical process with their own term signification methods within the framework of phonetic, morphological and syntactic rules or they seek to borrow the code of the term they will mark. In this context, this study aims to identify and classify according to which term signification method the names of the colors and verbs related to colors in Turkish is formed. One of the qualitative research methods, document analysis method was used in the study. The names of the colors within Kaymaz (1997)'s The Usage and Systematic of Color-Expressing Words in Turkish and Dialect and S. Küçük (2010)'s The Names And Specialities Of Colors In Turkey's Turkısh constitute the data of this study. Color names are classified under four main headings. As a result of the data analysis, 549 (43.2\%) of the total 1269 color names were "color names in the form of root, origin and body", 614 (48.4\%) "color names built with more than one meaning element", 71 (\%). 5,6) "verb root, derivation or stem about colors" and 35 (2.8\%) of them "idioms built with color names". The fact that the ability of Turkish to generate and derive is used effectively in color names as in other fields and that the names of colors vary according to the period, the characteristics of the geography and the culture in which they live are noteworthy.

Keywords: Color names, term signification, term signification methods

\section{Giriş}

\section{Türkçe ve renk adları}

İnsanlar, üzerinde yaşadıkları coğrafyada gördükleri, geliştirdikleri, ulaşabildikleri ne kadar soyut ya da somut kavram var ise bunların tamamını sözcükler/sözcük grupları... ile işaretler. Yaşadığı sürece kültürün ulaştı̆̆ bütün kavramları bu şekilde bünyesinde toplayan ve nesilden nesile aktaran dil, eriştiği her neslin hem kimliği hem de hafızası olur. Dilin canlı, ancak değişen taşıyıcıları olan bireyler ise yaratıcılıklarıyla kültürü ve dili ileriye götürürler (Gökberk 1997: 72; Mert ve Kavun, 2020: 53).

Nesilden nesile aktarılarak varlı̆̆ını devam ettiren dil, coğrafyanın niteliklerinden, inanç sistemlerinden, insanoğlunun yaşamından, teknolojinin gelişmesine kadar çok sayıda dinamikten etkilenir. Dil, hem bir iletişim aracı olması hem de çok sayıda kültürel kodu bünyesinde taşıması nedeniyle toplumsal değişikliklere bağlı olarak gelişmeye ve dolayısıyla da değişmeye mecburdur. Çok kısa sürede büyük değişikliklerin yaşandığı günümüzde daha önce hayatımızda olmayan ancak günümüzde -neredeyse- vazgeçilmez konuma gelen ulusal ve uluslararası değişiklikler, icatlar ve keşifler yeni kavram işaretlerine ihtiyacı beraberinde getirir. Bu kavram işaretlerinin toplumsal bir uzlaşı neticesinde toplum(lar)da kabul görerek dile dâhil edilmesi doğal bir süreçtir. "Biçimi ve şekli değişebilse de kelime türetme/kavram işareti oluşturma, her bir doğal dil için zorunluluk ve bir gerekliliktir. Bir dilin yaşayabilmesi ve varlığını devam ettirebilmesi için yeni kavramları sözcüklerle, sözcük gruplarıyla... işaretleyebilmesi gerekmektedir” (Paylan, 2015).

Tarihî süreçte kültürün geliştirdiği, karşllaştığı bütün kavramları soyutlayarak sözcük ya da sözcük gruplarıyla işaretleyerek bünyesinde toplandığı için bir dilin söz varlığından hareketle bağlı olduğu kültürün geliştirdiği dünyayı, ulaştığı kavramları, kültürün gelişmişlik düzeyini, kavramları algı şeklini...kısacası dile ve kültüre dair pek çok şeyi belirlemek mümkündür.

Özellikle sanayi ve bilgi toplumu düzeylerine kadar dili etkileyen, şekillendiren en önemli kavramlardan biri hiç kuşkusuz coğrafya ve coğrafyanın özellikleri olmuştur. Doğal dillerde 
coğrafyanın özelliklerine ve coğrafya - insan ilişkisinde coğrafi kavramların kültürdeki önemine göre bazı kavram ve kavram işaretlerinin sayısı ya da geçiş sıklı̆̆ı farlılık arz eder. Mesela Eskimolar'ın dilinde karla ilgili yaklaşık 50; "Bolivya ve Peru'da yaşayan Aymara adlı Kızılderili kabilesinin dilinde "patates" ile ilgili 200; Arapçada deveyle ilgili 5744, aslanla ilgili 500 ve yllanla ilgili ise 200 kavram işareti bulunmaktadır (Gündüzöz 2005: 215-229). Yukarıdaki örneklerde coğrafya - kültür ilişkisine bağlı olarak bazı dillerde belirli kavramlarla ilgili kavram işaretlerinin diğer dünya dillerine göre ciddi düzeyde farklılık arz ettiği görülmektedir. Bu da bize hem coğrafyanın dil ve kültürü ne kadar etkilediğini hem de dillerde, birtakım kavramlarla ilgili sözcüklerin fazlalığından, azlığından ya da dil içerisinde yer almamasından; kavramların dili kullananlar tarafından algılanma şekillerinden yola çlkarak bir kültürü ve dili büyük oranda tasvir etmenin mümkün olabileceğini göstermektedir.

Türkçe, tarihin eski çağlarından beri Çin'in batısından Avrupa'nın ortalarına, kuzey-güney istikâmetinde Sibirya tundralarından Hindistan'a kadar, koşulları çok ciddi düzeyde farklılık arz eden geniş bir coğrafyada yaşamaktadır. Dolayısıyla söz konusu coğrafyada olan her kavram, bir şekilde Türkçeye ve Türk kültürüne yansımıştır. Bu kavramların bir kısmını da Türkçenin kültür coğrafyasının sunduğu renk çeşitliliği oluşturmaktadır. Sadece Anadolu coğrafyası bile Türkçeyi renk adları bakımından pek çok dünya dilinden çok daha zengin kılmaya yetmiştir. Zira dünyanın pek çok bölgesinde iki mevsim yaşanırken, Anadolu'da dört mevsim de bütün özellikleriyle yaşanmakta; iklim koşulları, yüzey şekilleri gibi coğrafi özelliklere bağlı oluşan ve mevsimsel olarak farklılık arz eden bitki çeşitliliği, bitkilerdeki gelişime bağlı ortaya çıkan renk yelpazesi direkt olarak Türkçede karşılığını bulmuş ve böylece Türkçe çok zengin ve çeşitlilik gösteren geniş bir renk dünyasına sahip olmuştur (Küçük, 2010).

Renk kavramı Türkçe Sözlükte (2011), "Cisimler tarafından yansılanan ışı̆̆ı̆ gözde oluşturduğu duyum.” şeklinde tanımlanmıştır. Bir dilin sözvarlığı içinde renk ve renk algısı sadece fizikî, biyolojik ve kimyasal olarak algılanmamaktadır. Kültürler, renklere farklı anlamlar da yüklemekte ve bu anlamlardan hareketle renklerle ilgili yeni kavramlar da ortaya çlkabilmektedir. Halkbilim Terimleri Sözlüğünde (1978) "Halkbilimin en önemli konularından biri olan, insanlık çapında geniş bir uygulama alanı bulan, her toplumun kendi anlayış, yaşantı, gelenek ve göreneklerine göre doğa, doğaüstü ve kültürel olayları simgeleştirmekte kullanılan doğal oluşum” şeklinde tanımlanan renk kavramı insan doğasında farklılı̆̆ı, çeşitliliği ve değişimi de sembolize etmektedir.

Türkçe renk adlarını oluştururken çoğunlukla doğrudan doğruya çevredeki nesnelere dayanan aktarmalarla adlandırmaya gitmektedir (Aksan, 2015: 159-160). Bunun yanında gözlem, doğrudan doğruya nesnelerin adının kullanımıyla da Türkçede renk adları oluşturulmuştur (Aksan, 2015: 160).

Türkçe renklerle ilgili söz varlığını oluştururken üzerinde yaşadığı geniş coğrafyadan ve etkileşime girdiği dillerden/kültürlerden hem etkilenmiş hem de onları etkilemiştir: Mesela maviyi, beyazı Arapçadan; siyahı Farsçadan; bordoyu, griyi ve beji de Fransızcadan (TDK, 2011) alırken, akı Farsçaya, Rusçaya, Bulgarcaya, Arnavutçaya ve Makedoncaya; alayı Farsçaya ve Arapçaya; sarıyı Çinceye, Farsçaya, Rusçaya, Ermeniceye, Macarcaya, Bulgarcaya, Arnavutçaya ve Makedoncaya; karayı Çinceye, Farsçaya, Arapçaya, Romenceye, Rusçaya, Ermeniceye, Macarcaya, Bulgarcaya, Arnavutçaya, Makedoncaya ve Sırpçaya (Karaağaç, 2008) vermiştir. Bu durum, dile pek çok alanda olduğu gibi renk adları alanında da çeşitlilik ve zenginlik sağlamıştır. Bu bağlamda Kaymaz’n (1997) ve Küçük'ün (2010) yapmış oldukları çalışmalarda renklerle ilgili 1269 kavram işareti tespit edilmiştir. $\mathrm{Bu}$ çalışmada da söz konusu iki çalışmadaki renklerle ilgili kavram işaretleri, kavram işaretleme yöntemlerine göre tasnif edilerek ilgililerin dikkatlerine sunulmuştur.

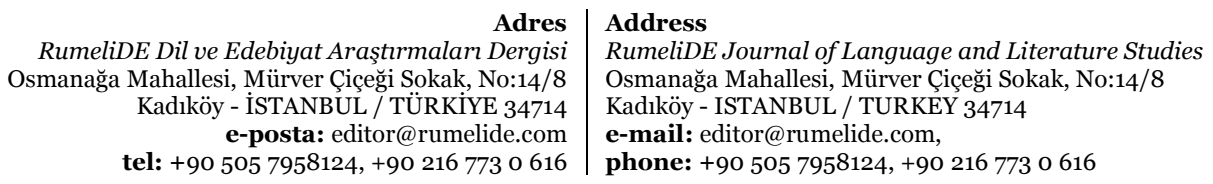


The analysis of the term significations related to color names in Turkey's Turkish according to the term signification methods / O. Mert; B. Şimşek (pp. 227-273)

\section{Türkçede kavramların işaretlemesi}

Diller, tarihî süreçte kültürün geliştirdiği, karşılaştığı kavramları ya fonetik, morfolojik ve sentaktik kuralları çerçevesinde kendine ait kavram işaretleme metotları ile işaretlemekte ya da işaretleyeceği kavramın kodunu ödünçleme yoluna gitmektedir.

Türkçe günümüzde kök üretmemektedir. Dolayısıyla mevcut durumda yeni geliştirilen ya da ulaşlan bir kavramın üretilecek yeni bir kök ile işaretlenme imkânı şu an için görünmemektedir. Bu durumda konuyla ilgili herkesin ilk aklına gelen yöntem mevcut olan bir kök ya da gövde üzerine yapım eki getirmek olmaktadır. Ancak burada da yapısal, fonolojik, morfolojik, sentaktik, semantik, pragmatik ve engelleme... gibi sınırlıklar yeni kavram işareti oluşturma olanaklarını bir taraftan standartlaştırırken diğer taraftan da daraltmaktadır.

Türkçede sözcük üretme yöntemleri ile ilgili olarak birçok farklı yaklaşım, yöntem olduğu belirtilmekte ve bunlar çeşitli şekillerde adlandırılmaktadır: Eker (2003) sözcük üretme yöntemlerini "kalıplaşma", "türetme", "birleştirme", "karma", "kısaltma”, “derleme", "tarama”, "anlam kayması", "ters türetme”, "uydurma", "işlevsel değişim" ve "ödünçleme" şeklinde on iki başlıkta belirtmektedir (ss. 322-330). Karaağaç (2012) Türkçede yapımlık ve çekimlik bağlı birimlerin yapısıyla ilgili yöntemleri şu şekilde belirtmektedir: "ekleme yöntemi”, büküm yöntemi”, “yineleme yöntemi”, “yardımcı sözler yöntemi”, "yer düzeni yöntemi” ve "vurgu yöntemi” (ss. 250-254). Aksan (2015) Türkçenin Sözvarh̆ğı adlı çalışmasında Türkçede sözcükleri, üretim şekillerine göre, dil içerisinde var olan "temel sözvarlığı", "yabancı sözcükler”, "deyimler”, "atasözleri”, “ilişki sözleri (kalıp sözler)”, "kalıplaşmış sözler”, "terimler" ve "çeviri sözcükler" olarak belirtmektedir (ss. 34-50). Sarı (2015) ise Türkçede Ekleme Dışı Sözcük Yapımı ve Sözlükselleşme adlı çalışmasında Türkçede yapım ekleri dışında sözcük yapımını "türetme”, "kırpma”, "eksiltme”, "karma”, "başharfleştirme”, "geri oluşum”, “işlev değişimi”, "genelleme", "ikileme", "birleştirme", "kopyalama", "yansıma", "uydurma” ve "eşleştirme” şeklinde sinıflandırmaktadır (ss. 40-83).

Yukarıdaki yaklaşımlar değerlendirildiğinde araştırmacıların önemli bir kısmının kalıcı kavram işaretlerini kök, köken ve gövde hâlindeki anlamlı dil ögeleri düzeyinde ele aldıkları görülmektedir ki bunun da sınırlılıkları vardır. Zira "dil ögelerinin taşıdıkları bilgi yükleri, kendilerini oluşturan fonetik veya grafik işaretlere dilin öngördüğ̈̈ ölçüye göre bölüştürülmüştür. Bu bakımdan, bir dil ögesini oluşturan ses veya harf sayısı arttıkça her ses veya harf üzerine düşen bilgi yükü; yine bir anlam ögesini oluşturan anlam ve görev ögelerinin sayısı arttıkça anlam ve görev ögeleri üzerine düşen bilgi yükü azalır" (Gemalmaz, 1995: 1-7). Yani sözcüğü oluşturan ses sayısı arttıkça sözcüğün anlaşılabilirliği azalırken, sözcüğü oluşturan ses sayısı azaldıkça da sözcüğün anlaşılabilirliği artar. Bu yüzden dünya dillerinde sözcüğü oluşturan ses sayıları insan beyninin algılama kapasitesi çerçevesinde sınırlanmıştır. Nitekim Türkçede kök ya da gövde üzerine eklenen her bir yapım eki, üzerine geldiği kök ya da gövdeyle birlikte yeni bir kalıcı kavram işareti oluştururken, sözcük boyunu uzattı̆̆ı için (sözcüğü oluşturan ses başına düşen anlam yükünü azalttığı için) de sözcüğün anlaşılabilirliğini düşürmektedir (Mert, 2008: 3-4; Alyılmaz, 2018: 12-13). Bu da göstermektedir ki, her ne kadar Türkçede kavram işaretleme söz konusu olduğunda ilk akla gelen metot "kök ya da gövde üzerine yapım eki getirme" olsa da söz konusu metodun belirli bir noktadan sonra kullanılabilirliği zayıftır. Dili kullananlar, insan beyninin çalışma ve algılama biçimine de uygun olarak yeni kavramları işaretlerken (mevcut kavram işaretlerine farklı anlamlar da yükleyerek) birden fazla sözcükten oluşan (çoğunlukla iki veya daha fazla parçalı/sözcüklü) kahıcı kavram işaretleme metotlarını geliştirmişlerdir. Çünkü

\footnotetext{
Adres | Address

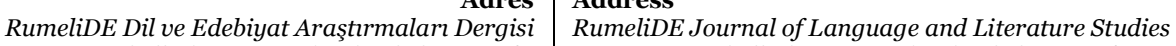
Osmanağa Mahallesi, Mürver Çiçeği Sokak, No:14/8 $\quad$ Osmanağa Mahallesi, Mürver Çiçeği Sokak, No:14/8 Kadıköy - İSTANBUL / TÜRKIYE 34714 Kadıköy - ISTANBUL / TURKEY 34714 e-posta: editor@rumelide.com e-mail: editor@rumelide.com, tel: +90 505 7958124, +90 2167730616 phone: +90 505 7958124, +90 2167730616
} 
anlamlı elemanlar arasında yer alan boşluk (space), hem sözcüğün telaffuzunu ve insan beyninin algılamasını kolaylaştırmakta; hem de sözcügün anlaşılabilirliğini artırmaktadır (Mert, 2008. 4).

Alyılmaz da konuyla ilgili olarak şunları kaydeder: "Bir kavramla ilgili yeni gelişme, değişme ve ayrışma söz konusu olduğunda, kavramlar arasında yakın veya uzak ilişki kurulduğunda ve onlarla ilgili düşünce farklılaştığında ortaya çıkan yeni “durum”u/“kavram”ı tek bir sözcükle karşılamak, ifade etmek güçleşir. Türkçenin kavramları işaretlerken başvurduğu sözcük tabanlarından yapım ekleriyle yeni kavramları adlandırma yöntemi bir anlamda yetersiz kalır” (Alyılmaz, 2018: 12). Yapım ekleriyle ilgili bütün bu sınırlılıklar dolayısıyla diller farklı sentaktik ilişkilerle birden fazla kavram işareti ile bir kavramı karşılama yoluna giderler. Bu şekilde yeni bir kavram işareti oluşturmak konuyla ilgili çalışmalarda genellikle "sözcük birleştirme/birleştirme" şeklinde nitelenmiştir. Konuyla ilgili olarak M. Tulum şunları kaydeder:

\begin{abstract}
Birleşik kelimeler, dilimizin söz dizimi kurallarına bağlı olarak kelimelerin belli birtakım kalıplara dökülmesi ile meydana gelir. Bu kalıplar söz içinde kelimelerin kavramları daha belirli hâle getirmek üzere anlamca birbirine yaklaşmaları ile şekil kazanan kelime gruplarıdır. Demek ki birleşik kelime, aslında bir kelime grubunun kelimelerinin tek bir kavramı karşlamak için anlamca tek bir kelime hâlinde bütünleşmesi, başka bir deyişle, sabit kavramlar kazanması ile meydana gelmiștir. Birleșimde, tek başlarına ayrı anlamlar tașıyan kelimeler, tek kelime gibi, bir tek kavramı karşılayacak şekilde anlamca kaynaşmıştır. Birleşik kelimeyi meydana getiren, asıl bu anlamca kaynaşmadır. Anlamca kaynaşma ve bütünleşme her birleşikte ayrı ayrı ve derece derecedir. Birleşenler kendi anlamlarını koruyabileceği gibi, bunlardan biri veya her ikisi öz anlamından uzaklaşmış da olabilir (Tulum, 1990: 31).
\end{abstract}

Tulum'un da yukarıda ifade ettiği gibi "birleşik sözcük/birleşik kelime/sözcük birleştirme..." terimleri, iki veya daha fazla sözcükten oluşan bir kavram işaretinin sözcükleri arasındaki sentaktik ilişkinin niteliğini ifade etmez. Eğer iki veya daha fazla sözcük ile bir kavram kalıcı olarak işaretlenebiliyor ise söz konusu sözcükler arasında sentaktik bir ilişki vardır. Zira "sözcük birleştirme" ya da "birleşik sözcük"; "belirtisiz isim tamlaması", "sıfat tamlaması", "zarf tamlaması” vb. gibi sentaktik yapılarla oluşturulmuş bir adlandırma değil, kavram işaretinin şekilsel olarak tasvirinden ibarettir. Dolayısıyla "birleşik sözcük" yerine Alyılmaz tarafından önerilen "Sentaktik/Söz Dizimsel Yöntemle İşaretlenmiş Kavram İşaret(i)leri” teriminin kullanılması daha uygun ve daha kapsayıcı görünmektedir (Alyılmaz, 2018: 16). Alyılmaz, ilgili çalı̧̧masında "Sentaktik/Söz Dizimsel Yöntemle İşaretlenmiş Kavram İşaretleri”ni aşağıdaki şekilde sınıflandırmıştır (Mert ve Kavun, 2020: 55-563):

1. Belirtisiz ad tamlaması yapısındaki kavram işaretleri

2. Sıfat tamlaması yapısındaki genel anlamlı kavram işaretleri

3. Birleşik eylem yapısındaki kavram işaretleri

3.1. Ad + eylemden oluşan kavram işaretleri

3.2. Eylem-bağ-fiil/ulaç eki + eylem yapısından oluşan kavram işaretleri

4. Belirteç + eylem yapısından oluşan kavram işaretleri

5. Nesne + eylem yapısından oluşan kavram işaretleri

6. Tekrar gruplarından / ikilemelerden oluşan kavram işaretleri

7. Diğer sözcük gruplarından oluşan kavram işaretleri

8. Cümlelerden oluşan kavram işaretleri (Alyılmaz 2018: 16).

Türkçe kavramları işaretlerken morfolojik ve sentaktik pek çok metot kullansa da diğer dünya dilleri gibi en fazla ödünçleme metodunu tercih etmektedir. Aynı durum renk adları için de geçerlidir.

\footnotetext{
RumeliDE Dil ve Edebiyat Arașturmalar Dergisi Osmanağa Mahallesi, Mürver Ciçeği Sokak, No:14/8 Kadıköy - ISTANBUL / TÜRKIYE 34714 e-posta: editor@rumelide.com tel: +90 505 7958124, +90 2167730616 
The analysis of the term significations related to color names in Turkey's Turkish according to the term signification methods / O. Mert; B. Şimşek (pp. 227-273)

Aksan (2007) dildeki kavramları dil içerisinde yer alan bir genelleme, soyutlama olarak nitelemektedir. Kavram işaretlemede dikkat çeken başka bir konu da nedenli ve nedensiz üretim durumudur. Guiraud, (1999) dil içi kavramların nedenliliği ve nedensizliği konusunda şunları söylemektedir: "gösterenle gösterilen arasında, konuşanların anlaşmasından doğan bir bağıntı bulunmadığı ölçüde gösterge nedensizdir. Varsa, göstergenin nedenli olduğu söylenir" (Guiraud, 1999: 35). Guiraud (1999) dil içerisinde kullanılan sözcüklerin çoğunluğunun temelde nedenli bir üretim sürecinden geçtiğini ve sonrasında dilin gelişim süreci içerisinde nedenliliğin anlaşlır olmaktan çlkarak sözcüğün nedensizleştiğini belirtir. Guiraud'ın bu görüşüne karşllık Saussure (1998) dil içi göstergelerin nedensiz olarak oluştuklarını belirtmektedir. Dilin tanımı içerisinde yer alan "gizli antlaşmalar sistemi” kavramı temelde Guiraud'ın görüşünü destekler niteliktedir. Günümüzde köken olarak belirtilen bazı kelimelerin kökleri bilinmese de bir kökten türediği, gösterenle gösterilen ilişkisi içerisinde olma durumu gibi varsayımlar sözcüğ̈̈n nedenli üretim olduğunu ve nedensizliğe doğru evrildiğini göstermektedir. Ayrıca bu durum diğer göstergeler için de varsayılabilir (öksüz, kuyumcu $v b$. $b k$. Öztürk, 2019). Bunların yanında dilin sentaktik yolla ürettiği söz varlığı içerisinde de bir nedenlilik durumu söz konusudur. Bu nedenliliğe benzetme, çağrışım $v b$. gerekçeler örnek gösterilebilir (Aksan, 2007). Örnek olarak; Dağ keçisi kavram işaretinde bir hayvan türü işaret edilmektedir. Dă̆ ve keçi kavram işaretleri, her ne kadar temellerinde nedenli olarak üretilme ihtimalleri olsa da, günümüzde dil içerisinde nedensizlik ilkesine göre yerlerini almıştır. Ancak yaban ortamında yaşayan ve keçi familyasından olan bir hayvan işaretlenirken yaşadığı yer ve familya çağrışımı kullanılarak iki sözcük bir araya getirilmiş ve aralarında sentaktik bir bağ kurulmuştur ve dă̆ keçisi kalıcı kavram işareti dilde yerini nedenlilik ilkesine göre almıştır. Benzer durum sentaktik usulle oluşturulmuş renk adları için de geçerlidir.

\section{Araştırma yöntemi}

Türkçede renklerle ilgili kavram işaretlerinin hangi kavram işaretleme yöntemlerine göre oluşturulduğunu tespit ve tasnif etmeyi amaçlayan bu çalışmada nitel araştırma yöntemlerinden doküman incelemesi yöntemi kullanılmıştır. "Doküman inceleme önceden oluşturulmuş var olan kayıt ve/veya belgelere dayalı veri toplama yöntemidir" (Ocak, 2019: 242). "Doküman incelemesi, araştırılması hedeflenen olgu veya olgular hakkında bilgi içeren yazılı materyallerin analizini kapsar" (Turgut, 2014: 239). Bunların yanında doküman incelemesinde doğrudan gözlem ile elde edilemeyecek bilgi ve veriler yazılı materyallerin incelenmesi neticesinde elde edilmektedir (Cansız Aktaş, 2014).

\section{Verilerin toplanması ve analizi}

Çalışmaya konu olan veriler, Z. Kaymaz’ın (1997) Türkiye Türkçesi ve Ağızlarında Renk Bildiren Kelimelerin Kullamılşı ve Sistematiği ile S. Küçük'ün (2010) Türkiye Türkçesinde Renk Adları ve Özellikleri adlı çalışmalarda yer alan renk adlarının doküman incelemesi yöntemiyle tespit ve tasnif edilmesiyle elde edilmiştir. Her ne kadar bu kapsamda Eminoğlu tarafından hazırlanan Türkçede Renkler Sözlüğü isimli kapsamlı bir çalışma olsa da Kaymaz ve Küçük’ün çalışmalarındaki renk adları çalışmanın amacı doğrultusunda elde edilecek verileri homojen bir şekilde sağlıyor olması açısından tercih edilmiştir. Her iki çalışmada yer alan tekrarlar ve çalışmayla ilgili olmayan farklı kullanımlar elendikten sonra toplam 1269 renk bildiren kavram işareti tespit edilmiştir. Tespit edilen renk adları alanyazında yapılan tarama ve ilgili konuda çalışmaları olan alan uzmanlarının görüşü alınarak belirlenen kavram işaretleme yöntemlerine göre tasnif edilmiştir. Sınıflandırma; "kök, köken ve gövde hâlindeki renk adları" ve "birden fazla anlam ögesiyle kurulmuş genel anlamlı kavram işaretleri" , "renklerle ilgili fiil; kök, köken ya da gövdeleri", "renk adlarıla kurulan deyimler" olarak dört ana

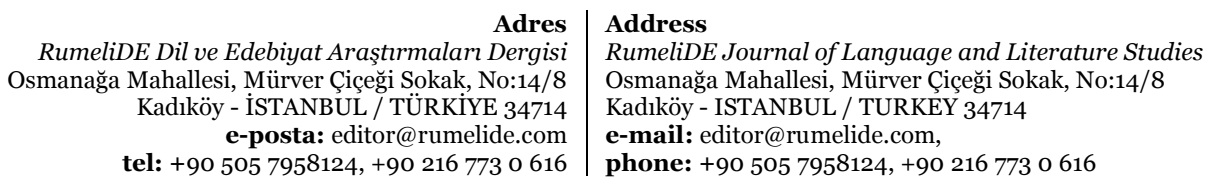


başlıkta yapılmıştır. Birden fazla anlam ögesiyle kurulmuş genel anlamlı kavram işaretleri ise kendi içerisinde: "belirtisiz isim tamlaması", "niteleme sıfatı+isim şeklinde kurulan renk adları", "isim+renkli sözcügüyle kurulmuş renk adları", "renk adı+fiil+sıfat fiil eki yapısıyla oluşan renk adları", "ikileme şeklinde kurulmuş renk adları", "isim+tamlanan eki+isim+/+lı/ şeklinde kurulan renk adları”, "isim+gibi yapısıyla kurulan renk adları", “özne+yüklemden oluşan renk adları” şeklinde alt başlıklara ayrılmıştır.

Verilerin analizinde nitel verileri analiz etmede kullanılan bir yöntem olan içerik analizi yöntemi kullanılmıştır. İçerik analizi, "insan davranışlarını ve doğasını belirlemek için çıkarımlarda bulunmaya yarayan, önceden belirlenmiş kurallara dayalı kodlamalarla veri içindeki bazı sözcüklerin daha küçük içerik kategorileri ile özetlendiği sistematik, yinelenebilir bir teknik" olarak tanımlanmaktadır (Boyraz ve Tepe, 2019: 306). Yıldırım ve Şimşek (2005) ise içerik analizinde temelde yapılan işlemin "birbirine benzeyen verileri belirli kavramlar ve temalar çerçevesinde bir araya getirmek ve bunları okuyucunun anlayabileceği bir biçimde düzenleyerek yorumlamak" (s. 227) olduğunu belirtirler. Bu doğrultuda elde edilen veriler çalışmanın amacına yönelik belirlenen kavram işaretleme yöntemlerine göre ilgili temalar altında sınıflandırılmış. Bu sınıflandırma neticesinde renk adlarının kavram işaretleme yöntemlerine göre dağılımları hem kullanım sayısı olarak hem de oransal olarak tespit edilmiş ve sayısal verilerle tablolaştırılmıştır.

\section{Bulgular}

\section{Renk adlarının kavram işaretleme yöntemlerine göre sınıflandırılması}

\subsection{Kök, köken, gövde ve ödünçleme hâlindeki renk adları}

Dil Bilimi Terimleri Sözlüğünde kök, birçok eş kaynaklı sözün yapısında bulunan anlamlı ve daha küçük ögelere ayrılamayan söz; köken, aslında gövde olmakla birlikte günümüzde kök gibi algılanan sözcük; gövde ise herhangi bir isim ya da fiil kökünün yapım eki alarak oluşturduğu yeni sözcük şeklinde tanımlanmıştır (Karaağaç, 2013: 564, ).

Çalışmada renk adlarıyla ilgili bir kısmı ödünçleme olan, bir kısmı da Türkçenin imkânlarıyla oluşturulan 549 adet kök, köken ya da gövde hâlinde oluşturulmuş kavram işareti tespit edilmiştir:

\begin{tabular}{|c|c|c|c|}
\hline abanoz & ahıtma & aklık & alalık \\
\hline ablak & ahmerlik & akma & alaşa \\
\hline abraşalabula & $\mathrm{ak}$ & akman & alca \\
\hline abraşık & akcacık & akrak & algin \\
\hline açığırak & akça & akşın & alık / alıh \\
\hline açık & akçalı & al & alizarin \\
\hline ağamsı & akçıl & ala & allı \\
\hline ağaran & akçıllı & alaca & allık \\
\hline ağarantı & akımsı & alacalı & almes \\
\hline ağarımtı & akıtma & alacalık & aloş \\
\hline ağartı & akıtmaç & alacık & alpak \\
\hline ağartu & akıtmalı & alaç & alsevi \\
\hline ahcil & aklan & alajik & altınımsı \\
\hline $\begin{array}{r}\text { Rum } \\
\text { Osmana }\end{array}$ & 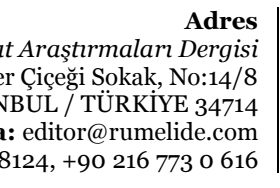 & $\begin{array}{l}\text { Address } \\
\text { RumeliDE Journal of } \\
\text { Osmanağa Mahallesi } \\
\text { Kadkaöy - ISTANBUI } \\
\text { e-mail: editor@rum } \\
\text { phone: + } 90505795\end{array}$ & $\begin{array}{l}\text { re Studies } \\
:: 14 / 8\end{array}$ \\
\hline
\end{tabular}


The analysis of the term significations related to color names in Turkey's Turkish according to the term signification methods / O. Mert; B. Şimşek (pp. 227-273)

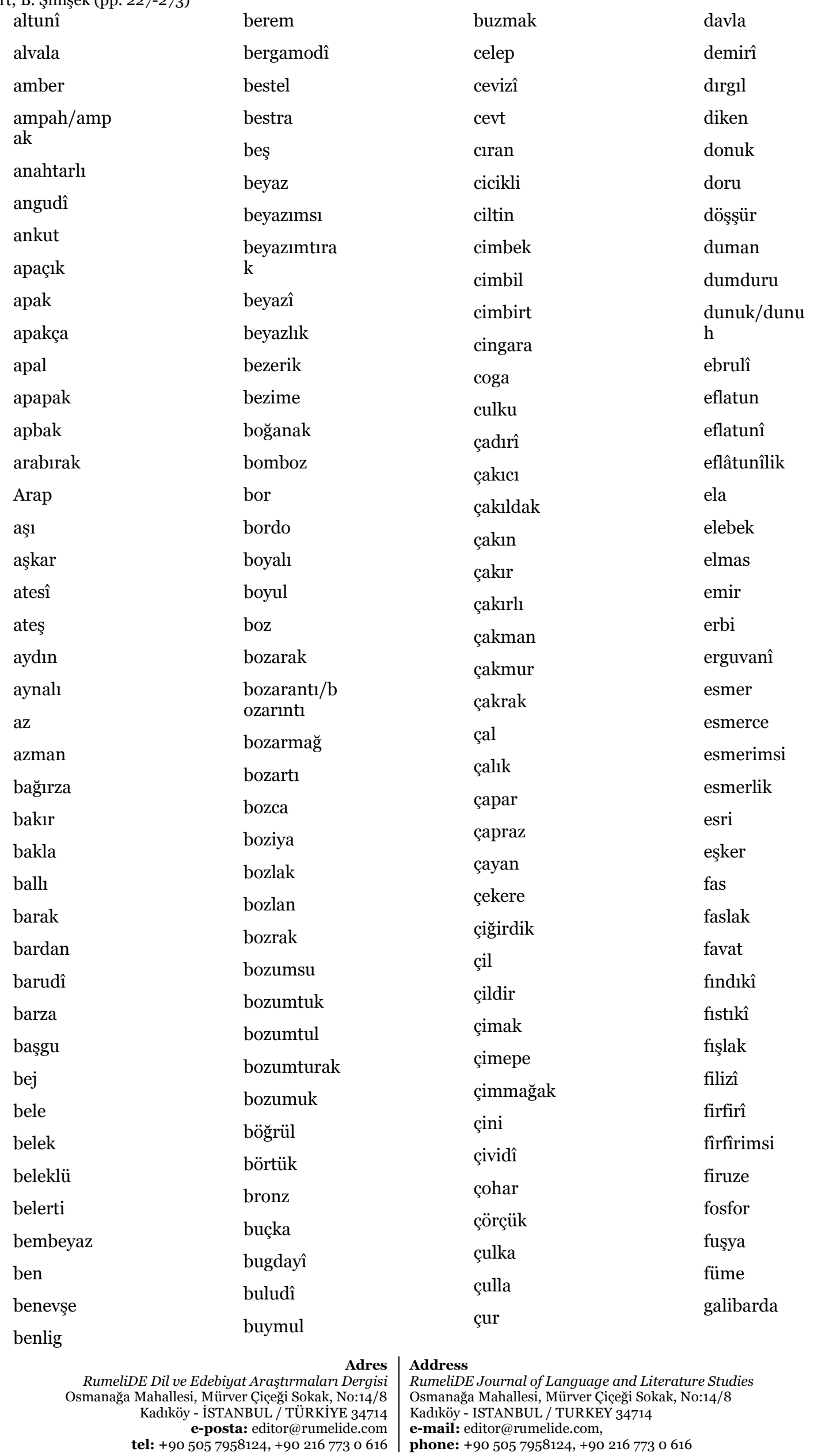


Türkiye Türkçesindeki renklerle ilgili kavram işaretlerinin kavram işaretleme yöntemlerine göre incelenmesi / O. Mert; B.

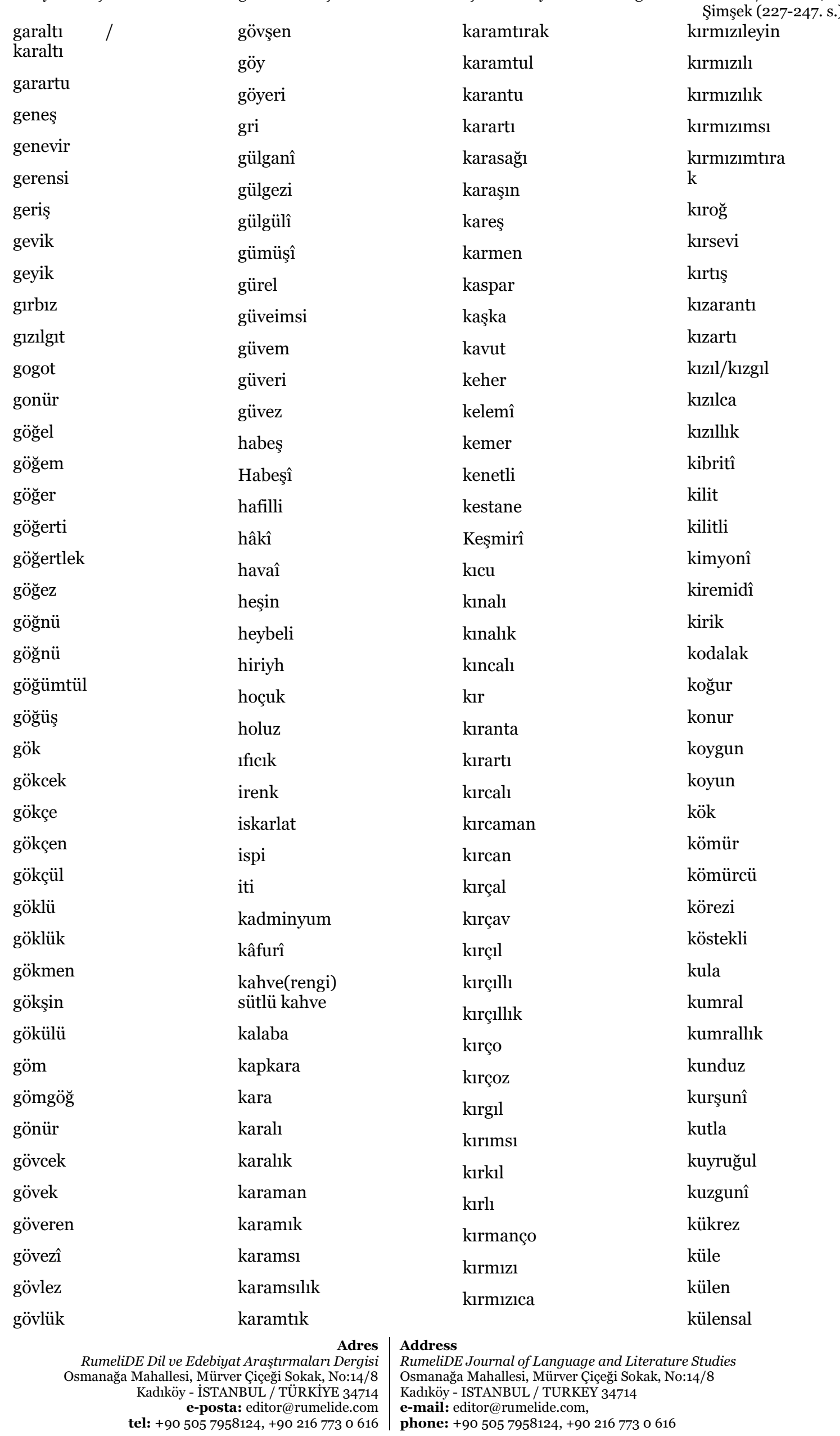


The analysis of the term significations related to color names in Turkey's Turkish according to the term signification methods / O. Mert; B. Şimşek (pp. 227-273)

\begin{tabular}{|c|c|c|c|}
\hline $\begin{array}{l}\text { külensan } \\
\text { kp. }\end{array}$ & morluk & sarım & tetir \\
\hline küleysi & morsevi & sarımsı & tetirli \\
\hline kündükü & morumsu & sarımtırak & tig \\
\hline küren & morumtırak & sarışın & tirşe \\
\hline laciverdî & mosmor & sarışınca & tok/toh \\
\hline lacivert & muğal & sarışınlık & ton \\
\hline lâden & müllük & sarkanak & toprak \\
\hline lâk & narıncı & sasık/sasuk & toru \\
\hline lâl & narınç & sedefî̀ & tunç \\
\hline leylaki & navrike & seki & turkuaz \\
\hline limonî & neftî & sekili & turuncu \\
\hline magnezyum & nohudî & semavî & tutkun \\
\hline manav & oflaz & sığınak & tüssü \\
\hline mancarak & ömür & Sinık & tütek \\
\hline manoma & pal & siklamen & uğralı \\
\hline maron & palak & simit & uğut \\
\hline maskal & pati & simsiyah & ürün \\
\hline masmavi & patlıcanî & sincabî & vermiyon \\
\hline maun & patul & sinil & yağal \\
\hline mavi & pedrik & sitil & yagren \\
\hline mavice & pembe & siyah & yagız/yağıız \\
\hline mavileyin & pembelik & siyahımsı & yanaklı \\
\hline mavili & pembemsi & siyahımtırak & yanal/yanıl \\
\hline mavilik & penlik & siyahî & yeşerti \\
\hline mavimsi & pespembe & siyahlık & yaprak \\
\hline mavimtırak & pezik & solgun & yaşmaklı \\
\hline maviş & portokalî & soluk & yemyeşil \\
\hline maviyo & postallı & sur & yeşi \\
\hline maz & renkli & süt & yeşil \\
\hline mencer & safir & şalgamî & yeşilimsi \\
\hline menesfer & safran & şarabî & yeşilimsirek \\
\hline mengiş & sağas & şayak & yeşilimtırak \\
\hline mercanî & sakar & şebüş & yeşilli \\
\hline mışık & samanî & şll & yeşillik \\
\hline mimoza & sanlı & taba & yıldız \\
\hline monus & sapsarı & tahinî & yiti \\
\hline mor & sargut & tarçınî & zavraklı \\
\hline morarıntı & sarı & targll & zebella \\
\hline morartı & sarica & tarsı & zencî \\
\hline morçuk & sarllgit & tekir & zer \\
\hline mordilak & sarılık & tepel & zerî \\
\hline \multicolumn{2}{|c|}{ 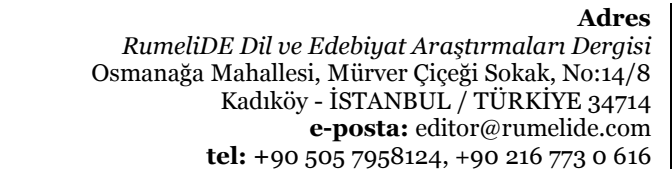 } & \multicolumn{2}{|c|}{\begin{tabular}{|l} 
Address \\
RumeliDE Journal of Language and Literature S S \\
Osmanağa Mahallesi, Mürver Ciçeği Sokak, No:14 \\
Kadıöy - ISTANBUL / TURKEY 34714 \\
e-mail: editor@ @rumelide.com, \\
phone: +90 505 7958124, +90 216773 o 616
\end{tabular}} \\
\hline
\end{tabular}


Türkiye Türkçesindeki renklerle ilgili kavram işaretlerinin kavram işaretleme yöntemlerine göre incelenmesi / O. Mert; B.

$\begin{array}{llll}\text { zeytunî } & \text { zifirî } & \text { zilgara } & \text { Şimşek } \\ \text { zifir } & \text { zift } & \text { zümrürü }\end{array}$

\subsection{Birden fazla anlam ögesiyle kurulmuş renklerle ilgili kavram işaretleri}

\subsubsection{Belirtisiz isim tamlaması şeklinde kurulmuş renk adları}

Gemalmaz (2010) belirtisiz isim tamlamaları ile ilgili şunları belirtir: "Birçok dilde olduğu gibi Türkçede de kavram işaretleme yollarının başında gelir. Bir isim tamlaması en az iki isimle kurulur. Bir şeyin bir diğer şey için olması, belirtisiz isim tamlamalarında, tamlayanı, genel olarak amaca yönelik bir niteleyen durumuna koyarak diğer oluș bildiren niteleme sıfatlarından ayırır. Bu hâl bir şeyin en kalıcı niteliği olduğu için belirtisiz isim tamlamaları, tamlamalar arasında en kalıcı kuruluşları oluştururlar. Gelişmiş her dilde çok sayıda isim, belirtisiz isim tamlamaları kurma yoluyla yapılmıştır. Günümüzde hızla gelişen teknoloji ve onun soyut ve somut ürünlerinin adlandırılmasında en çok başvurulan yol belirtisiz isim tamlamalarıdır. Bu yol eklemeyle yapılan adlandırmalara göre ekonomik olmamasına rağmen amaca yönelik olduğu için ifadeye daha bir anlaşılırlık kazandırmaktadır. Ekonomi daha çok tamlama yoluyla yapılan kuruluşların kelimelerinin ilk harf veya bazı hecelerinin birleştirilmesiyle sağlanmaktadır” (s. 253).

"Soyut ve somut kavramları karşılayan belirtisiz isim tamlaması yapısında kurulu kavram işaretlerinin bir kısmı birleşik bir kısmı ise ayrı yazılmaktadır. Belirtisiz ad tamlaması yapısındaki kavram işaretlerinin bir kısmı genel anlamlı kavram işaretleri (cins / tür $v d$. adları) yaparken bir kısmı ise özel anlamlı kavram işaretleri yapmaktadırlar" (Alyılmaz, 2018: 16).

İncelememizde toplam 1269 renk adından belirtisiz isim tamlaması yoluyla kurulmuş 361 renk adı tespit edilmiştir. Bunlar;

\begin{tabular}{|c|c|c|c|}
\hline abanoz karası & \multicolumn{2}{|c|}{ ayva rengi } & böcek kabuğu \\
\hline abanoz siyahı & \multicolumn{2}{|c|}{ ayva sarısı } & böğürtlen siyahı \\
\hline Akdeniz mavisi & \multicolumn{2}{|c|}{ bakır çalığı } & bronz rengi \\
\hline akide pembesi & \multicolumn{2}{|c|}{ bakır kırı } & buğday esmeri \\
\hline akrep kızılı & \multicolumn{2}{|c|}{ bakır kızılı } & buğday rengi \\
\hline akşam güneşi & \multicolumn{2}{|c|}{ bakır pası } & bulut grisi \\
\hline alev kırmızısı & \multicolumn{2}{|c|}{ bakır rengi } & Bursa yeşili \\
\hline altın rengi & \multicolumn{2}{|c|}{ bakla çiçeği } & burun kanı \\
\hline altın sarısı & \multicolumn{2}{|c|}{ bakla kırı } & burun kanı rengi \\
\hline altın yeşili & \multicolumn{2}{|c|}{ bal köpüğü } & buz mavisi \\
\hline Ankara armudu & \multicolumn{2}{|c|}{ bal rengi } & cam kırığı \\
\hline & \multicolumn{2}{|c|}{ barut mavisi } & cam mavisi \\
\hline Arap daşağ & \multicolumn{2}{|c|}{ barut rengi } & cam yeşili \\
\hline Arap helimesi & \multicolumn{2}{|c|}{ bayrak rengi } & camgöbeği yeşili \\
\hline asit yeşili & \multicolumn{2}{|c|}{ bebek mavisi } & can eriği yeşili \\
\hline asker yeşili & \multicolumn{2}{|c|}{ bet rengi } & canfes kızılı \\
\hline asma filizi & \multicolumn{2}{|c|}{ beton rengi } & civa mavisi \\
\hline aşı boyası & \multicolumn{2}{|c|}{ biftek kırmızısı } & civciv sarısı \\
\hline ateş kırmızısı & \multicolumn{2}{|c|}{ billur rengi } & çağla rengi \\
\hline ateş sarısı & \multicolumn{2}{|c|}{ bonbon pembesi } & çağla yeşili \\
\hline ayva pişmişi & \multicolumn{2}{|c|}{ boncuk mavisi } & çam yeşili \\
\hline $\begin{array}{r}\text { RumeliDE Di } \\
\text { Osmanağa Maha } \\
\text { Kadı } \\
\text { tel: + }\end{array}$ & $\begin{array}{r}\text { Adres } \\
\text { nergisi } \\
\text { No:14/8 } \\
\text { YE } 34714 \\
\text { elide.com } \\
773 \text { o } 616\end{array}$ & $\begin{array}{l}\text { Address } \\
\text { RumeliDE } \\
\text { Osmanağa } \\
\text { Kadıköy - I } \\
\text { e-mail: ed } \\
\text { phone: +c }\end{array}$ & $\begin{array}{l}\text { terature Studies } \\
\text { rak, No:14/8 } \\
\text { o } 616\end{array}$ \\
\hline
\end{tabular}


The analysis of the term significations related to color names in Turkey's Turkish according to the term signification methods /

O. Mert; B. Şimşek (pp. 227-273)

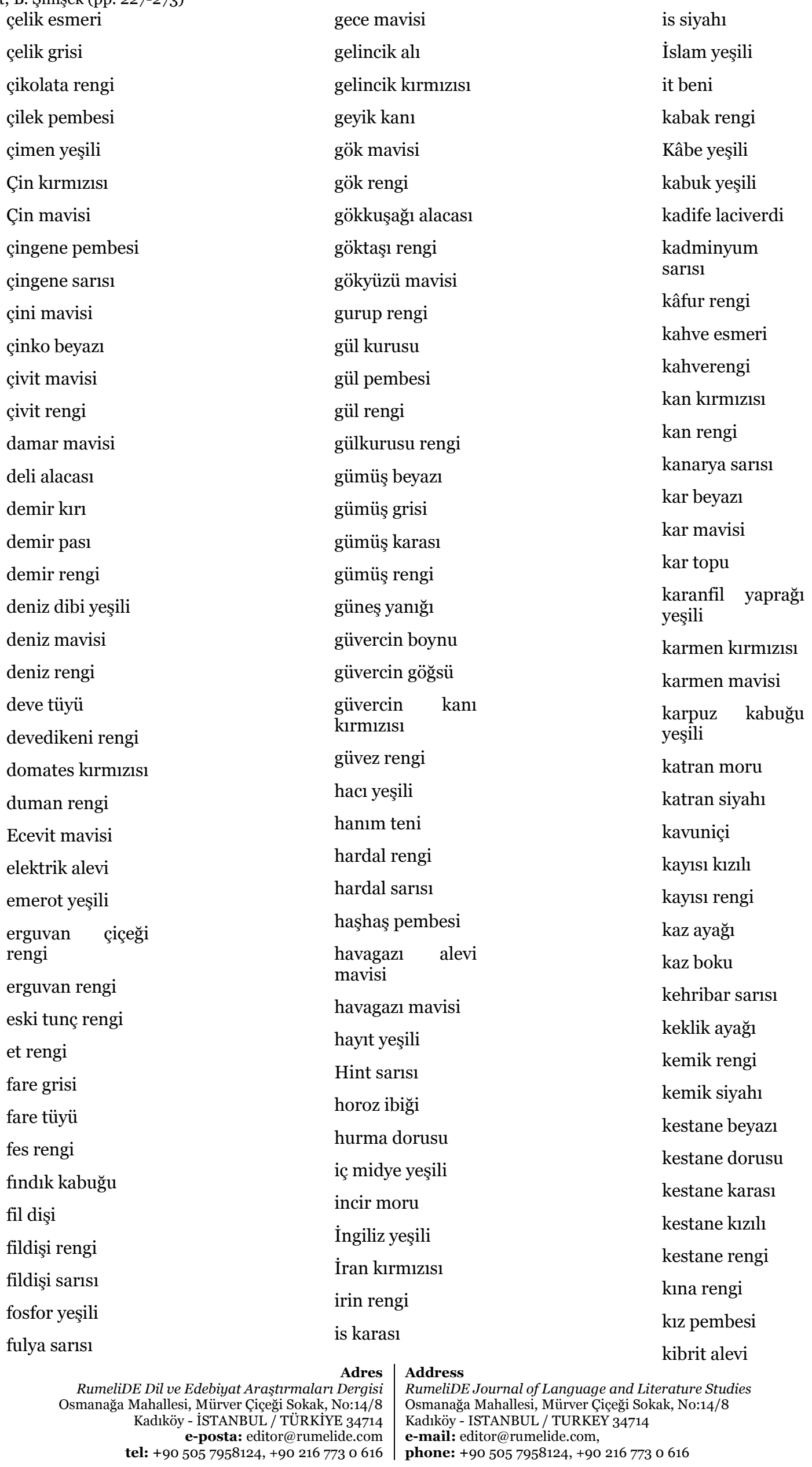


Türkiye Türkçesindeki renklerle ilgili kavram işaretlerinin kavram işaretleme yöntemlerine göre incelenmesi / O. Mert; B.

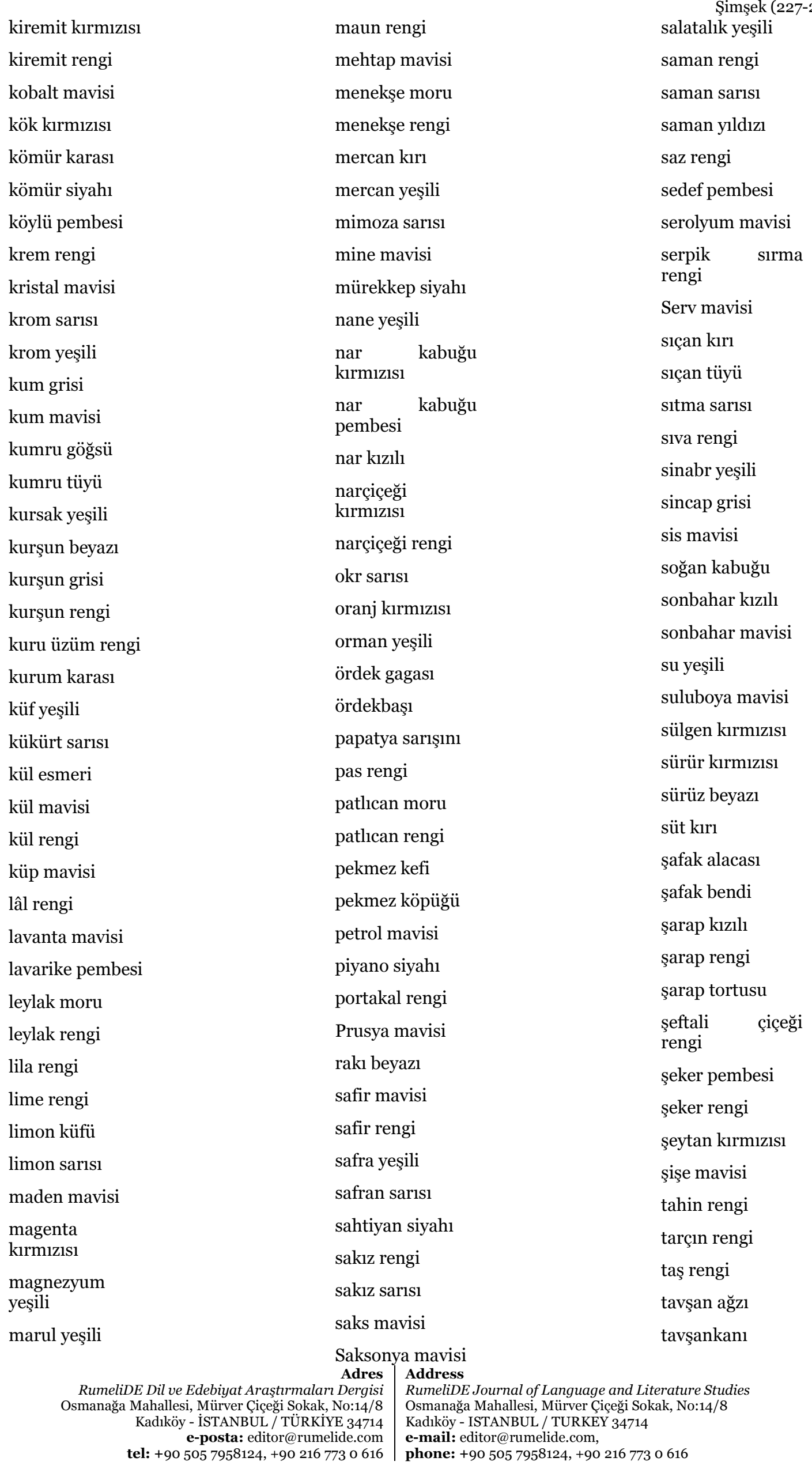


The analysis of the term significations related to color names in Turkey's Turkish according to the term signification methods / O. Mert; B. Şimşek (pp. 227-273)

$\begin{array}{lll}\text { tavus yeşili } & \text { Türk yeşili } & \text { yağ yeşili } \\ \text { tebeşir beyazı } & \text { tütün rengi } & \text { yaldız sarısı } \\ \text { ten rengi } & \text { tütün sarışını } & \text { yaprak kırmızısı } \\ \text { toprak beyazı } & \text { utremer mavisi } & \text { yaprak kurusu } \\ \text { toprak rengi } & \text { uzay mavisi } & \text { yavruağazı } \\ \text { tozpembesi } & \text { üveyik kırı } & \text { yonca yeşili } \\ \text { tuğla rengi } & \text { üzüm yeşili } & \text { yosun yeşili } \\ \text { turkuaz mavisi } & \text { Van Dyck esmeri } & \text { yumurta sarısı } \\ \text { turkuaz yeşili } & \text { vapur dumanı } & \text { zehir yeşili } \\ \text { turna kırı } & \text { Venedik kırmızısı } & \text { zeytin ağacı yeşili } \\ \text { turp filizi } & \text { vermiyon } & \text { zeytin rengi } \\ \text { türbe yeşili } & \text { kırmızısı } & \text { zeytin siyahı } \\ \text { Türk çinisi } & \text { veronez yeşili } & \text { zeytin yeşili } \\ \text { Türk kırmızısı } & \text { vişne rengi } & \text { zümrüt rengi } \\ \text { Türk mavisi } & \text { vişneçürüğü } & \text { zümrüt yeşili }\end{array}$

Ekleme: Belirtisiz ad tamlaması yapısındaki kavram işaretlerinin belirtilen ögesinin üzerinde yer alan belirtilen eki /+(s)I/, zaman zaman işaretsiz kullanılır (Gemalmaz, 2010: 251-259; Alyılmaz, C. 2011: 515-527). İncelenen renk adları içinde tamlanan eki /+(s)I/'nın işaretsiz kullanıldığı örnekler şunlardır:

$\begin{array}{ll}\text { bakla kır(1) } & \text { ördekbaşı yeşil(i) } \\ \text { çini mavi(si) } & \text { pamuk kır(1) } \\ \text { et renk(i) } & \text { pekmez al(1) } \\ \text { gül pembe(si) } & \text { sardunya pembe(si) } \\ \text { gül renk(i) } & \text { süt beyaz(1) } \\ \text { kehribar esmer(i) } & \text { süt mavi(si) } \\ \text { kurt kula(sı) } & \text { üveyik kır(1) } \\ \text { mercan kır(1) } & \text { zeytin kara(sı) }\end{array}$

\subsubsection{Niteleme sıfatı+isim şeklinde kurulan renk adları}

Türkçede genel anlamlı kalıcı kavram işareti oluşturma metotlarından biri de niteleme sıfatı + isim şeklinde kurulan tamlamalardır. Bilindiği gibi Türkçede her "nitelik sıfatı + isim"den kurulu tamlama genel anlamlı kalıcı kavram işareti yapmaz. Ama Türkçede genel anlamlı kalıcı kavram işaretleme metotlarından biri "niteleme sıfatı + isim"den oluşan tamlamalardır. Burada belirleyici olan tamlayan ve tamlanan arasındaki ilişkinin geçiciliği ya da kahıcılığıdır. Mesela "yeşil ağaç, yeşil gömlek, yeşil otomobil" gibi örneklerde yeşil sözcüğü ile nitelediği isimler arasındaki ilişki geçici olduğundan, tamlayan ile tamlanan birlikte kalıcı bir kavram işareti oluşturmadı̆̆ından bu örneklerde kavramın geçici olarak işaretlendiği görülmektedir. Ancak "yeşil ışık, yeşil oy, yeşil kuşak, yeşil kart, yeşil pasaport, yeşil saha, yeşilbaş, yeşil salata...” gibi örneklerde yeşil sıfatı, nitelediği isimle birlikte genel anlamlı yeni bir kavram işareti oluşturmuş ve sözlükte de bu kavram işaretleri yerini almıştır (Mert ve Kavun, 2020: 56 ).

Türkçede "niteleme sıfatı + isim" şeklinde kurulmuş kalıcı kavram işaretlerinin sayısı "belirtisiz isim tamlaması” şeklinde kurulan kalıcı kavram işaretlerine oranla daha azdır. Türkçe Sözlük (2011)'te "niteleme sıfatı+isim" şeklinde oluşturulmuş toplam 4580 kavram işareti varken (Mert ve Kavun, Adres Address

RumeliDE Dil ve Edebiyat Araştırmalar Dergisi $\quad$ RumeliDE Journal of Language and Literature Studies Osmanağa Mahallesi, Mürver Çiçeği Sokak, No:14/8 Osmanağa Mahallesi, Mürver Çiçeği Sokak, No:14/8 Kadıköy - ISTANBUL / TÜRKIYE 34714 Kadıköy - ISTANBUL / TURKEY 34714 e-posta: editor@rumelide.com e-mail: editor@rumelide.com, tel: +90 505 7958124, +90 216773 o 616 phone: +90 505 7958124, +90 2167730616 
Türkiye Türkçesindeki renklerle ilgili kavram işaretlerinin kavram işaretleme yöntemlerine göre incelenmesi / O. Mert; B. Şimşek (227-247. s.)

2020: 102), "belirtisiz isim tamlaması" şeklinde kurulmuş 7251 kavram işareti (Sönmez, 2018: 15) bulunmaktadır. Bu çalışmada da belirtisiz isim tamlaması yoluyla oluşturulan kavram işaretlerinin sayısının niteleme sıfatı+isim"den kurulu kavram işaretlerinden daha fazla olduğu tespit edilmiştir. Zira bu çalışmada incelenen 1269 renk adından belirtisiz isim tamlaması yoluyla oluşturulmuş renk adı sayısı 361 iken "niteleme sıfatı+isim” şeklinde oluşturulan renk adı sayısı ise 175’tir.

Yapılan çalışmada tespit edilen niteleme sıfatı+isim şeklinde kurulan renk adları aşağıdaki gibidir:

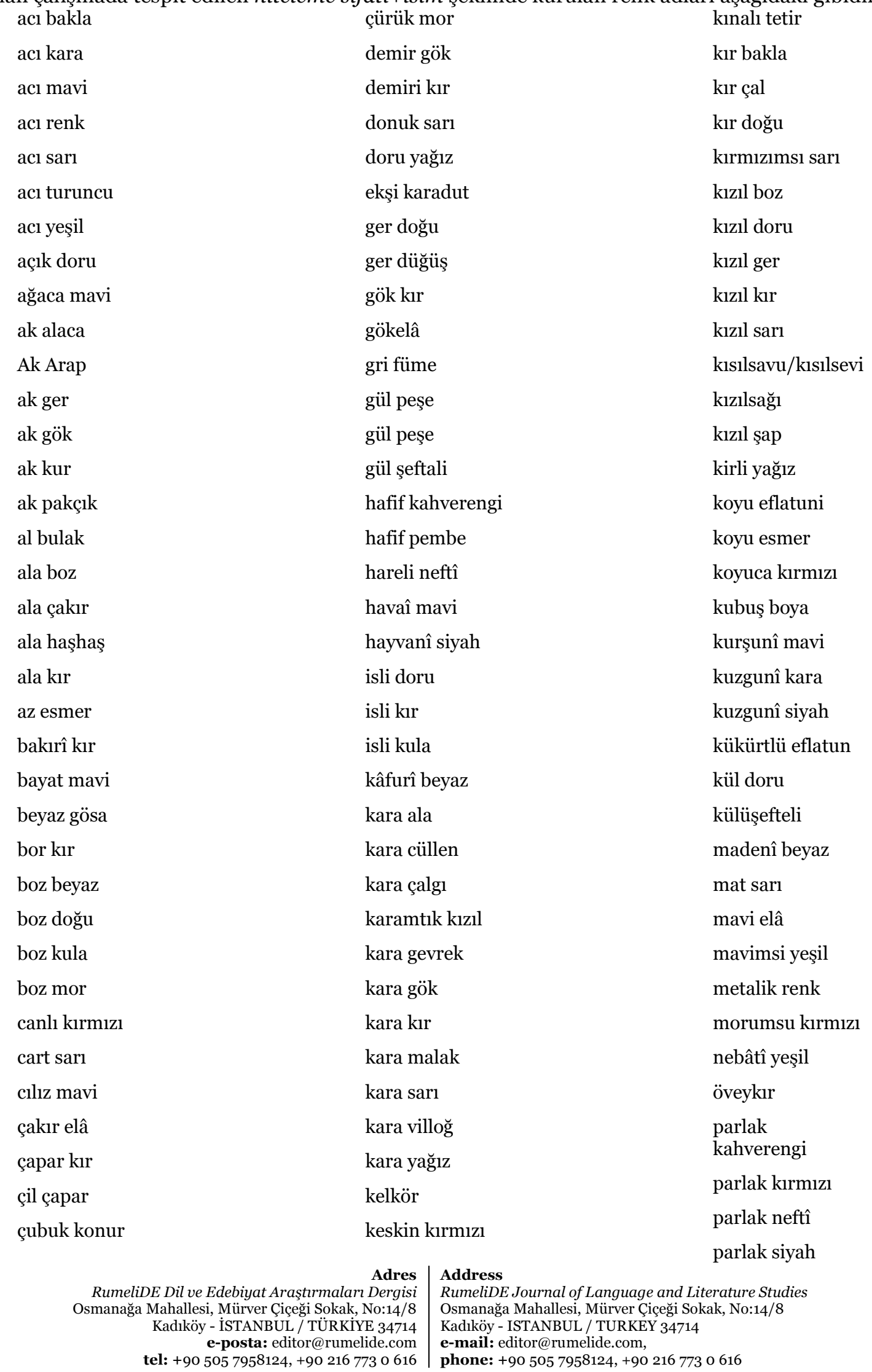


The analysis of the term significations related to color names in Turkey's Turkish according to the term signification methods / O. Mert; B. Şimşek (pp. 227-273)

\begin{tabular}{lll} 
paslı sarı & sırmalı lacivert & tüm ak \\
pastel mavi & sima sakar & tüm kara \\
pastel renk & soğuk beyaz & türlü tevür \\
pastel yeşil & soğuk mavi & uçuk mavi \\
pembe beyaz & solgun kızıl & uçuk pembe \\
pişmiş ayva & soluk kahverengi & uçuk sarı \\
pullu kır & süt beyaz & uğurlu seki \\
sarı aşı & süt kır & uğursuz seki \\
sarı baybak & süt mavi & üçlük sakar \\
sarı bayrak & sütlü kahve & yağız doru \\
sarı boz & sütlü kahverengi & yağlı kara \\
sarı çapar & sütlü lacivert & yağlı siyah \\
sarı elâ & şaprak sakar & yanık al \\
sarı esmer & tok yeşil & yarım ay \\
sarı ger & toprak boya & yıldızlı kır \\
sarı konur & toz pembe & zehirli mavi \\
sarı yağız & tozlu kahverengi & zifirî laciverd \\
sedefli beyaz & tozlu sarı & \\
semavî mavi & turuncu kızıl & \\
\hline
\end{tabular}

Ekleme 1: Çalışmada, isim+çalar/çalan+renk adı şeklinde sıfat tamlamasıyla kurulmuş 6 renk adı tespit edilmiştir:

$\begin{array}{ll}\text { eflatuna çalar koyu pembe } & \text { kahverengiye çalan yeşil renk } \\ \text { eflatuna çalar mavi } & \text { yeşile çalar gök rengi } \\ \text { gümüşîye çalan koyu mavi } & \text { yeşile çalar mor }\end{array}$

Ekleme 2: Çalışmada, isim + A yakın+renk adı şeklinde sıfat tamlamasıyla kurulmuş 3 renk adı tespit edilmiştir:

beyaza yakın gümüş rengi siyaha yakın esmer

mora yakın kırmızı

Ekleme 3: renk adı+/+tırak/+renk adı şeklinde sıfat tamlamasıyla kurulmuş 3 renk adı tespit edilmiştir:

karamtırak kızıl

mavimtırak

kırmızımtırak esmer

külrengi

\subsection{3. İsim+renkli sözcüğüyle kurulmuş renk adları}

Çalışmada, isim+renkli sözcüğüyle kurulmuş 5 renk adı tespit edilmiştir. Bunlar;

Bismark renkli

buğday renkli

karaca renkli

\begin{tabular}{|c|c|}
\hline & ess \\
\hline RumeliDE Dil ve Edebiyat Araştırmalar De & Journal of Language and Literature Studies \\
\hline Osmanağa Mahallesi, Mürver Çiçeği Sokak, No:14/8 & Osmanağa Mahallesi, Mürver Çiçeği Sokak, No:14/8 \\
\hline Kadıköy - İSTANBUL / TÜRKİYE 34714 & Kadıköy - ISTANBUL / TURKEY 34714 \\
\hline $\begin{array}{r}\text { e-posta: editor@rumelide.com } \\
\text { tel: }+905057958124,+902167730616\end{array}$ & $\begin{array}{l}\text { e-mail: editor@rumelide.com, } \\
\text { phone: +90 505 7958124, +90 } 216773 \text { o } 616\end{array}$ \\
\hline
\end{tabular}




\subsubsection{Renk adı+fiil+sıfat fiil eki yapısıyla oluşan renk adları}

Çalışmada, renk adı+fiil+sıfat fiil eki şeklinde kurulmuş 7 renk adı tespit edilmiştir:

$\begin{array}{lll}\text { ala bakar } & \text { kızıl gelen } & \text { yeşil gelen } \\ \text { beyaz gelen } & \text { mor gelen } & \\ \text { gece girmez } & \text { sarı gelen } & \end{array}$

\subsection{5. İkileme şeklinde kurulmuş renk adları}

Çalışmada, ikileme şeklinde kurulmuş 40 renk adı tespit edilmiştir:

$\begin{array}{lll}\text { abaz abaz } & \text { alaş bulaş } & \text { kanak sarkanak } \\ \text { ak pak } & \text { alaz daraz } & \text { kara kara } \\ \text { ak pakçık } & \text { alca belce } & \text { kara kura } \\ \text { ak pakça } & \text { allı güllü } & \text { kara kuru } \\ \text { akça pakça } & \text { allı morlu } & \text { karalı beyazlı } \\ \text { aklı akçalı } & \text { allı pullu } & \text { kel kör } \\ \text { aklı karalı } & \text { allı yeşilli } & \text { kırmızı kırmızı } \\ \text { al al } & \text { beyaz beyaz } & \text { kırt kızkırt } \\ \text { ala bele } & \text { celep celep } & \text { mavi mavi } \\ \text { ala bula } & \text { cicili bicili } & \text { sarı sarı } \\ \text { al(a) bulak } & \text { çiğil çiğil } & \text { yanardöner } \\ \text { alaca bulaca } & \text { çipil çipil } & \text { zak zak } \\ \text { alacalı bulacalı } & \text { ebru ebru } & \\ \text { alalı bulalı } & \text { gır gır } & \end{array}$

\subsection{6. İsim+tamlanan eki+isim+/+lI/ şeklinde kurulan renk adları}

Çalışmada, isim+tamlanan eki+isim+/+lI/ şeklinde kurulmuş 4 renk adı tespit edilmiştir:
ağzı kenetli
ağzı mühürlü
ağzı kilitli
eli kefenli

\subsection{7. İsim+gibi yapısıyla kurulan renk adları}

Çalışmada, isim+gibi şeklinde kurulmuş 21 renk adı tespit edilmiştir:

$\begin{array}{lll}\text { altın gibi } & \text { kâğıt gibi } & \text { kuzgun gibi } \\ \text { Arap gibi } & \text { katran gibi } & \text { kül gibi } \\ \text { billur gibi } & \text { kaymak gibi } & \text { limon gibi } \\ \text { bronz gibi } & \text { kehribar gibi } & \text { mermer gibi } \\ \text { elma gibi } & \text { kireç gibi } & \text { sakız gibi } \\ \text { fildişi gibi } & \text { kömür gibi } & \text { turna gözü gibi } \\ \text { inci gibi } & \text { köpük gibi } & \text { zümrüt gibi }\end{array}$


The analysis of the term significations related to color names in Turkey's Turkish according to the term signification methods / O. Mert; B. Şimşek (pp. 227-273)

\subsection{8. Özne+yüklemden oluşan renk adları}

Çalışmada, özne+yüklemden oluşan bir adet renk adı tespit edilmiştir:

kar yă̆dı

\subsection{Renklerle ilgili fiil kök, köken ya da gövdeleri:}

Çalışmada, renklerle ilgili 71 fiil tespit edilmiştir:

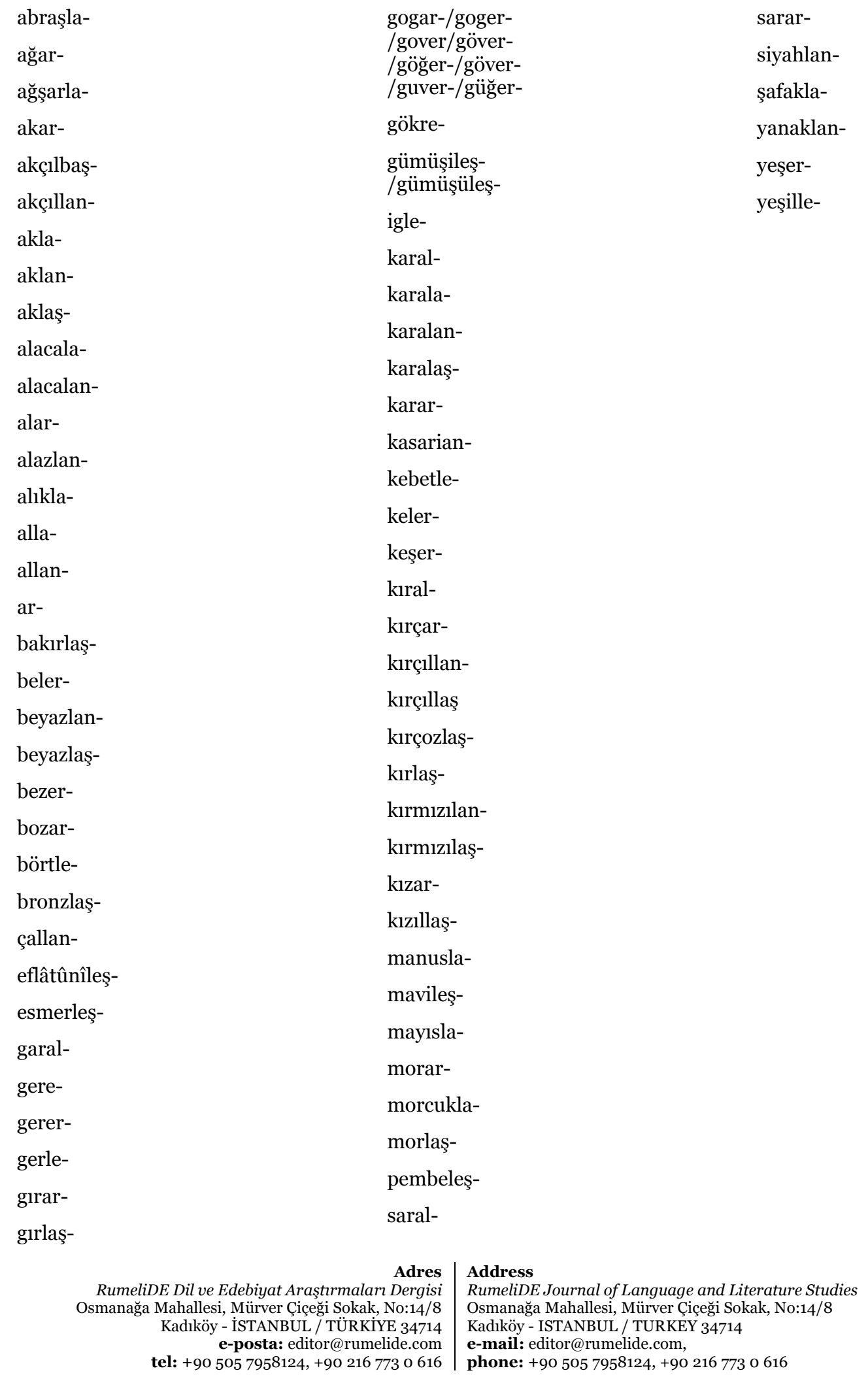




\subsection{Renk adlariyla kurulan deyimler}

Çalışmada, renk adlarıyla kurulan 35 deyim tespit edilmiştir:

$\begin{array}{ll}\text { Abaz abaz ol- } & \text { gözü karar- } \\ \text { ak bas- } & \text { gün gal- } \\ \text { ak düş- } & \text { kır düş- } \\ \text { akla karayı seç- } & \text { kızıl bozul ol- } \\ \text { al üstüne al giy- } & \text { kızlla çal- } \\ \text { al üstüne mor giy- } & \text { kireç gibi ol- } \\ \text { ala düş- } & \text { kireç kesil- } \\ \text { ala getir- } & \text { levir levir yan- } \\ \text { Arap gibi ol- } & \text { mosmor ol- } \\ \text { ayva gibi ol- } & \text { nevli dön- } \\ \text { ben düş- } & \text { rengi kaç- } \\ \text { beyaza çek- } & \text { rengi uç- } \\ \text { beyaza çıar- } & \text { renk al- } \\ \text { bok yemenin gülpembesi } & \text { renk at- } \\ \text { boya at- } & \text { renk renk ol- } \\ \text { boz düş- } & \text { renkten renge gir- } \\ \text { donu bozuk ol- } & \text { sapsarı kesil- }\end{array}$

et ben ol-

\section{Sonuç}

Türkçe renk çeşitliliğini işaretlerken bazen kendine ait kavram işaretleme metotlarını kullanmış bazen de renk adını ödünçleme yoluna gitmiştir. Aşağıdaki tabloda çalışmada incelenen 1269 renk adının kavram işaretleme yöntemlerine göre dağılımları verilmiştir.

Tablo 13. Renklerle ilgili kavram işaretlerinin Türkçede kavram işaretleme yöntemlerine/şekillerine göre dağılımları

\section{Kavramın işaretlenme yöntemi / şekli}

Kök, köken ve gövde hâlindeki renk adları

\section{Birden fazla anlam ögesiyle kurulmuş genel anlamlı kavram işaretleri}

Belirtisiz isim tamlaması

Örnek sayısı

Oranı

Niteleme sıfatı+isim şeklinde kurulan renk adları

isim+renkli sözcügüule kurulmuş renk adları

renk adı+fiil+sıfat fiil eki yapısıyla oluşan renk adları

İkileme şeklinde kurulmuş renk adları

isim+tamlanan eki+isim+/+lI/ şeklinde kurulan renk adları

Adres

RumeliDE Dil ve Edebiyat Araştırmaları Dergisi Osmanağa Mahallesi, Mürver Çiçeği Sokak, No:14/8 Kadıköy - İSTANBUL / TÜRKIYE 34714 e-posta: editor@rumelide.com tel: +90 $5057958124,+902167730616$
Address

RumeliDE Journal of Language and Literature Studies Osmanağa Mahallesi, Mürver Çiçeği Sokak, No:14/8

Kadıköy - ISTANBUL / TURKEY 34714

e-mail: editor@rumelide.com,

phone: +90 505 7958124, +90 2167730616 
The analysis of the term significations related to color names in Turkey's Turkish according to the term signification methods / O. Mert; B. Şimşek (pp. 227-247)

\begin{tabular}{lll}
\multicolumn{1}{c}{ isim+gibi yapısıyla kurulan renk adları } & 21 & 1.7 \\
$\quad$ özne+yüklemden oluşan renk adları & 1 & 0.07 \\
Renklerle ilgili fiil kök, köken ya da gövdeleri & 71 & 5.6 \\
Renk adlarıyla kurulan deyimler & 35 & 2.8 \\
Toplam & $\mathbf{1 2 6 9}$ & $\mathbf{1 0 0}$
\end{tabular}

Tablo incelendiğinde 1269 renk adının 549’u (\%43,2) kök, köken, gövde ve ödünçleme hâlinde kullanıldığı görülmektedir. Birden fazla anlam ögesiyle kurulmuş genel anlamlı renk adlarına bakıldığında ise toplam $614(\% 48,4)$ renk adı tespit edilmiştir. Bu örneklerden 361’i (\%28.5) belirtisiz isim tamlaması yoluyla işaretlenmiştir. Bu metodu $175(\% 13,8)$ örnekle niteleme sıfatı+isim şeklinde kurulan renk adları, $40(\% 3,1)$ örnekle ikileme şeklinde kurulmuş renk adları, $21(\% 1,7)$ örnekle isim+gibi yapısıyla kurulan renk adları, 7 örnekle $(\% 0,6)$ renk adı+fiil+sıfat fiil eki yapısıyla oluşan renk adları, $5(\% \mathrm{O}, 4)$ örnekle isim+renkli sözcüğ̈̈yle kurulmuş renk adları, $4(\% \mathrm{o}, 3)$ örnekle isim+tamlanan eki+isim+/+lI/ şeklinde kurulan renk adlar, 1 (\%o,07) örnekle özne+yüklemden oluşan renk adları takip etmektedir. Ayrıca $71(\% 5,6)$ örnek renklerle ilgili fiil kök, köken ya da gövdelerinden, $35(\% 2,8)$ örnek ise renk adlarıyla kurulan deyimler'den oluşmaktadır.

Tabloda yer alan veriler değerlendirildiğinde renk adlarının işaretlenmesinde Türkçenin kavram işareti üretme sürecinde sıklıkla kullandığı yöntemlerin renk adı üretmekte de benzer oranlarda kullanıldığı görülmektedir. Tabloda dikkat çeken bir oran ise $(614-\% 48,4)$ birden çok anlam ögesiyle kurulmuş renk adının; kök, köken, gövde ve ödünçleme şeklinde kullanılan renk adından $(549-\% 43,2)$ fazla olmasıdır. Bu noktada renk adlarının üretim sürecinde kök, köken ve gövde hâlinde üretimin azaldığı görülmektedir. Mevcut renk adları büyük oranda korunurken yeni renk adları kültürel, teknolojik, ekonomik $v b$. gerekçelerle belirtisiz isim tamlamaları ya da sıfat tamlamaları gibi birden çok anlam ögesiyle kurulmaya başlanmıştır. Bu bağlamda özellikle boya üretim sektörünce üretilen yeni ürünlere isim verme yarışının etkisi göz ardı edilmemelidir (Doğan, 2015; Oğuz, 2020). Bunların yanında Türkçede benzetme ve çağrışım $v b$. gerekçelerle renk adlarıyla ile ilgili fiil $(\% 5,6)$ ve deyimler $(\% 2,8)$ de üretilmiştir.

İhtiyaca göre kendini geliştiren dil, renk adlarında da bu ihtiyacı her zaman görmüş ve dönemin, coğrafyanın, iklimin, kültürün, dinin ve etkileşime girilen diğer dillerin etkisiyle renk adlarını söz varlığ içerisine çeşitlendirerek eklemiştir.

Sonuç olarak renk adları insanın çevresine olan egemenliğinin, anlamlandırma ve tanımlama yeteneğinin bir göstergesi olarak dilin içerisinde varllğını göstermektedir. Burada Türkçenin üretme ve türetme yeteneğinin diğer alanlarda olduğu gibi renk adlarında da etkili bir şekilde kullanıldığı; döneme, coğrafyaya ve içinde yaşanılan kültüre göre renk adlarının çeşitlilik gösterdiği dikkati çekmektedir.

\section{Kaynakça}

Acıpayamlı, O. (1978). Halkbilim Terimleri Sözlüğü, Ankara: Türk Dil Kurumu.

Aksan, D. (2007). Her yönüyle dil. Ankara: Türk Dil Kurumu.

Aksan, D. (2015). Türkçenin sözvarlığı. Ankara: Bilgi.

Alyılmaz, C. (2011). Zamir n'si eski bir iyelik ekinin kalıntısı olabilir mi? Türk Gramerinin Sorunları III Bildirileri içinde (ss. 515-527). Ankara: Türk Dil Kurumu.

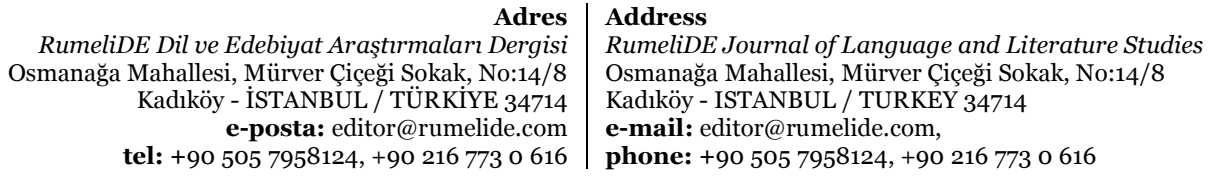

tel: +90 505 7958124, +90 2167730616

phone: +90 $5057958124,+90216773$ o 616 
Alyılmaz, S. (2018). Türkçede birden fazla anlam ögesiyle (sentaktik yolla) kavramların işaretlenmesi. Çukurova Üniversitesi Türkoloji Araştırmaları Dergisi. 3(1), 11-25.

Boyraz, S., \& Tepe, M. E. (2019). Verilerin analizi. G. Ocak (Ed.), Eğitimde bilimsel araştırma yöntemleri içinde (ss. 274-320). Ankara: Pegem Akademi.

Doğan, Nuh. (2015). Türkiye Türkçesi söz varlığının yeni renkleri-ad bilimsel bir inceleme, Dede Korkut Dergisi, 7, 12-37.

Eker, S. (2003). Çağdaş Türk dili (2. Baskı). Ankara: Grafiker.

Eminoğlu, H. (2014). Türkçede renkler sözlüğ̈̈̈. Ankara: Gazi.

Gemalmaz, E. (1995) Türkçe'nin morfo-sentaktik yapısının fonolojisine etkileri, Atatürk Üniversitesi Türkiyat Araşttrmaları Enstitüsü Dergisi, 1(3),1-7

Gemalmaz, E. (2010). Türkçenin derin yapısı. Ankara: Belen.

Gökberk, M. (1997). Değişen dünya değişen dil. İstanbul: Yapı Kredi.

Guiraud, P. (1999). Anlambilim, (B. Vardar çev.). İstanbul: Multilingual.

Gündüzöz, S. (2005). Arapçada kültür-dil ilişkisi: Arapça'nın yapılanması ve algılanmasında etkili öğeler. Dinbilimleri Akademik Araşttrma Dergisi, 5 (3) , 215-229.

Karaağaç, G. (2008). Türkçe verintiler sözlüğü, Ankara: Türk Dil Kurumu.

Karaağaç, G. (2012). Türkçenin dil bilgisi. Ankara: Akçă̆.

Karaağaç, G. (2013). Dil bilimi terimleri sözlüğ̈̈. Ankara: Türk Dil Kurumu.

Kaymaz, Z. (1997). Türkiye Türkçesi ve ağızlarında renk bildiren kelimelerin kullanılışı ve sistematiği, TDAY, Belleten, 251-341.

Küçük, S. (2010). Türkiye Türkçesinde renk adları ve özellikleri. Uluslararası Sosyal Araşttrmalar Dergisi, 3(10), 420-427.

Mert, O \& Kavun, M. (2020). Nitelik sıfatı+isim şeklinde kurulan kalıcı kavram işaretleri üzerine bir inceleme, F. Çelebi (Ed.) Beşeri ve Sosyal Bilimlerde Kavramsal ve Uygulamah Araştırmalar içinde (ss. 52-103). İzmir: Duvar.

Mert, O. (2008). Orhun Yazıtlarında kullanılan işaretsiz (/.ø./) görev ögeleri. Atatürk Üniversitesi Türkiyat Araştırmaları Enstitüsü Dergisi, 38, ss. 1-20.

Ocak, G. (2019). Bilimsel araştırmalarda kullanılan veri toplama yolları. G. Ocak (Ed.), Eğitimde bilimsel araştırma yöntemleri içinde (ss. 274-320). Ankara: Pegem Akademi.

Oğuz Bülbül, B. (2020). İç cephe boya adlarının nedenliliği ya da nedensizliği üzerine bir inceleme, G. Kurt (Ed.), Filoloji alaninda teori ve araştırmalar II içinde (ss. 2019-2040). Ankara: Gece Kitaplığı.

Öztürk, J. (2019). Türkiye Türkçesinde kökü açlk olarak görülmeyen kelimeler. Kafdağı 4 (2), 107-133.

Paylan, K. (2015). Türkçede kelime türetme yollarına genel bir bakış (Yüksek Lisans Tezi). Yükseköğretim Kurulu Ulusal Tez Merkezi’nden edinilmiştir. (Tez No. 406992)

Sarı, İ. (2015). Türkçede ekleme dışı sözcük yapımı ve sözlükselleşme (Doktora Tezi). Yükseköğretim Kurulu Ulusal Tez Merkezi’nden edinilmiştir. (Tez No. 399599)

Saussure, F. (1998). Genel dilbilim dersleri, (B. Vardar çev.). İstanbul: Multilingual.

Sönmez, A. (2018). Türkçe Sözlük’teki birleşik kelimeler üzerine inceleme (Yüksek Lisans Yükseköğretim Kurulu Ulusal Tez Merkezi’nden edinilmiştir. (Tez No. 511464)

Tulum, M. (1990). Eleştiriler ve cevaplar: Dil tartışmalarından gerçekler. Ankara: TDK.

Türk Dil Kurumu. (2011). Türkçe sözlük. Ankara.

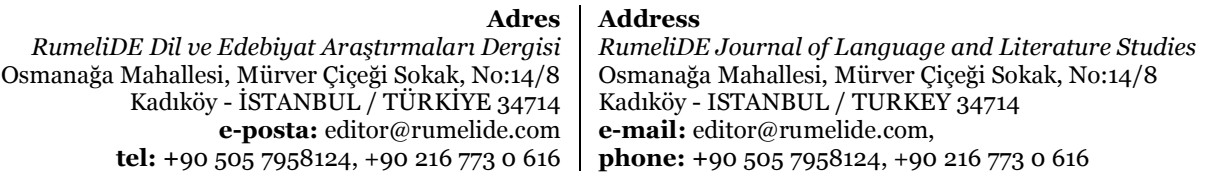

